\title{
From Biosphere to Semiosphere to Social Lifeworlds Biology as an Understanding Social Science
}

\author{
Dedicated to Thure von Uexkuell (1908-2004)
}

\section{Günther Witzany}

\author{
Guenther Witzany \\ PHILOSOPHISCHE PRAXIS \\ प्रLOS \\ Vogelsangstraße 18c · A-5111-Buermoos · Salzburg - Austria \\ witzany@sbg.at
}

\begin{abstract}
The change could not be more radical. Biology, as a classical natural science, has celebrated numerous successes. Examining its subject matter from a reductionistic, materialistic point of view has led to exceptional knowledge and given rise to dozens of sub-disciplines. Unfortunately, by pursuing such detail, satisfactory answers to central questions - What is life? How did it originate and how do we view ourselves as living beings? - have been lost in a universe of analytical units. Yet not entirely! A transdisciplinary network is evolving: it goes beyond reductionistic biology, beyond vitalism or a rekindled (metaphysical) enchantment of nature. It is increasingly able to provide better answers to these questions than firmly established, traditional, mechanistic biology:
\end{abstract}

(1.) a semiotics that transcends Peirce, James and Morris to serve as a basis for the interpretation of sign processes in biosemiotics (Kull 2005), ${ }^{1}$ (2.) developmental biologists, embryologists and epigeneticists who have turned the paradigm "DNA-RNA-Protein-everything else" (Arthur Kornberg) on its head and who try to understand protein bodies as contextdependent interpreters of the genetic text, (3.) a philosophy that reconstructs biology as an understanding social science which describes the rule-governed sign-mediated interactions of cell individuals to mega-populations in their lifeworlds. ${ }^{2}$

Keywords: pragmatic turn, rule-governed sign-mediated interactions, Mitwelt, symbiogenesis, global symbiotic interdependence.

\footnotetext{
1 "Within the major currents of modern semiotics, the most influential ones are the Peirce-Morris mainstream (pragmati(ci)st and related ones), the "semiological" mainstream (the diverse structuralisms incl. poststructuralism), and those of biosemiotics and sociosemiotics" (Bernard 2005).

2 Short version was referred at the 4th Gatherings in Biosemiotics, Prague 2004.
} 


\section{Introduction}

A pragmatic philosophy of biology which founds biology as an understanding social science has to leave behind metaphysical positions such as ontosemantic approaches, which suggest that correct sentences in a formalizable language could depict physical reality on a one-to-one basis, i.e., that the meaning of contents is equivalent to objective reality. Once this fundamental error regarding the conditions of basic knowledge (Wittgenstein I, linguistic turn: Carnap, Logical Empiricism, Russel, Tarski) was refuted by Wittgenstein II, speech act theory and pragmatic theory of action in the pragmatic turn clearly revealed a fundamental need for scientists to pragmatically reflect on the language they use: (a) when they study objects, and (b) raise validity claims for their scientific knowledge within the community of investigators.

\section{How Does Understanding Function?}

Any attempt to deal with biology as an understanding social science requires examining how understanding functions. Wittgenstein once said "To understand a proposition means to know what is the case if it is true." And he said "Something is a proposition only within a language. To understand a proposition means to understand a language", and we may add "to understand a language game." What he meant was that it is not words, but rather sentences that we understand: we understand sentences in a language in which we are linguistically competent; we understand sentences in which the speaker presents propositions interconnected with validity claims. We do not understand natural phenomena, empirical observations, physiological processes, physical principles, but rather sentences and actions that underlie grammatical, semantic and pragmatic rules that we share with the members of a linguistic community. Thus, understanding is not a one-sided, reactive form of action but is directed toward the meaning of an utterance that, beyond its communicatory character, also has the intention to establish intersubjectivity: What does the speaker want to do with his words, with his actions and body-embedded expressions? (Austin 1962, Searle 1976).

This, however, means that problems with understanding can arise if we don't share the rules that an uttering individual is following. As we know, this can pertain to three levels: (a) We do not share the rules by which the individual correctly combines the uttered (linguistic and/or action-related) symbols, i.e., we do not understand the grammar; (b) we cannot recognize the rules by which the individual establishes a relationship between (linguistic and/or action-related) signs and the designated objects; or (c) we fail to recognize the rules by which the individual establishes a relationship between the (linguistic and/or actionrelated) signs and himself (e.g.: Which validity claims does the speaker combine with his utterances?).

"In order to understand an utterance in the paradigm case of a speech act oriented to reaching understanding, the interpreter has to be familiar with the conditions of its validity; he has to know under what conditions the validity claim linked with it is acceptable or would have to be acknowledged by the hearer. But where could the interpreter obtain this knowledge if not from the context of the observed communication or from comparable contexts? (...) Thus the interpreter cannot become clear about the semantic content of an expression independently of the action contexts in which participants react to the expression with a "yes" or "no" or an abstention. And he does not understand these yes/no positions if he cannot make clear to himself the positions they do. (...) But if, in order to understand an expression, the interpreter must bring to mind the reasons with which the speaker would, if necessary and under suitable conditions, defend its validity, he is himself drawn into the process of assessing validity claims. For reasons are of such a nature that they cannot be described in the attitude of a third person" (Habermas 1984: 115-116). 
There is no syntax, no grammar, no meaning, no semantic entity without the 3 levels of grammatical, semantic and pragmatic rules of sign usage. All attempts to reduce one of these three levels of rules on one another would be a pre-wittgensteinian and a pre-peirceian argumentation and leads us back directly to metaphysical debates. K.O. Apel has worked out the types of the abstractive fallacies which follow reduction of levels (Apel 1974, Witzany 2005).

The precondition for understanding is an intersubjectively shared lifeworld of a linguistic community that shares the grammatical, semantic and pragmatic rules of sign usage. A prerequisite for understanding is, therefore, a historically evolved social lifeworld, which provides the basis for the historical development of the commonly shared language.

The historicity of the respective ordinary languages is manifested in the use of numerous expressions and culturally specific language games that differ more or less strongly from region to region. Everyday life in a Greenland fishing village features expressions and linguistic actions that are largely foreign or unknown to ordinary language in an Austrian wine-growing region. Nonetheless, the two are able to communicate with one another and even convey complex information if they are willing and able to translate their regionally influenced means of expression into a universal language such as English or to learn each other's language. They can then communicate their historically evolved regional culture and the discussion partner can increasingly better understand the utterances and peculiarities because the elementary requirements of life and the human condition as such are similar and pursue intentions that can be universalized: Humans strive for sociality or, as Aristotle wrote - "summum bonum". They pursue a certain degree of freedom, social justice, a need for meaningful activity, artistic creation, a commonly enacted and individually experienced spirituality, the production of myth and ritus. They make an effort to achieve the absence of or to avoid disease, distress and pain, and practice dealing with existential experiences such as birth, sexuality, pleasure, happiness, pain, suffering and death. Human cultural communities organize themselves around such issues, which provide the foundation for exchanging experiences in a narrative form.

"In coming to an understanding with one another about their situation, participants in communication stand in a cultural tradition which they use and at the same time renew; in coordinating their actions via intersubjective recognition of criticizable validity claims, they rely on memberships in social groups and at the same time reinforce the integration of the latter; through participating in interaction with competent reference persons, growing children internalize the value orientations of their social groups and acquire generalized capabilities for action. (...) Under the functional aspect of reaching understanding communicative action serves the transmission and renewal of cultural knowledge; under the aspect of coordinating action, it serves social integration and the establishment of group solidarity; under the aspect of socialization, it serves the formation of personal identities" (Habermas 1987: 208).

Such ordinary languages are not pure, formalizable languages but languages that are based on historically evolved, authentic lifeworlds. "It is the shared speech situation (...) which constitutes the center of the lifeworld on which all social spaces (...) and historical dimensions (...) converge prior to any objectivation by measurement" (Habermas 1994: 68).

We do not need $3^{\text {rd }}$ person's observations and experimental studies to understand how understanding functions. We can analyze the ordinary language that we ourselves use, in the $1^{\text {st }}$ or $2^{\text {nd }}$ person, i.e., as a participant; here, we can find all the elements of linguistic and communicative action. In a first step, we can determine that utterances such as requests, orders, questions, insinuations, accusations, approval, declarations, fabrications, etc. are regulative, imperative, expressive, objectifying, innovative, etc. actions with the intention of: (a) establishing a commonly held understanding about something, and (b) establishing an intersubjective relationship of action that enables a common, coordinated action or appropriate division of labor. 
If we pursue this one level deeper, then we determine that our utterances are correlated with expectations in our counterpart, who we suppose is principally capable of understanding our utterances, i.e., of correctly gaining the sense of what we have expressed. I omit here that particular form of strategic communication that one-sidedly tries to manipulate the discussion partner, but restrict myself to communication that is oriented towards mutual understanding. In such a communication, oriented toward achieving understanding, the expectations are reciprocal. In order to reach an understanding with another speaker and establish an interrelationship, four validity claims must be fulfilled independently of the cultural frameworks: (1.) an utterance must be understandable. If the partner cannot understand the utterance, then he or she cannot answer (respond) appropriately. (2.) The utterance must be correct, i.e. the expressions used must be the correct ones to express the situation (normative rightness). (3.) It must be true - the expressed situation must correspond with reality (propositional truth). (4.) It must be sincere, i.e. be meant in the manner in which it was expressed.

The understanding of intersubjective acts of human communication is directed at three levels, on that of (a) linguistic utterances, (b) actions, and (c) body-embedded expressions. Linguistic utterances have an evident (locutionary) communicatory aspect. Depending on the intention, they can use this grammatically clearly visible structure to mean something different: This represents their not-immediately-evident (illocutionary) force, which prompts those who are addressed to react in one way or another to one and the same grammatical structure of an expression. And they are part of an (perlocutionary) action, perlocutionary acts are performed with the intention of producing a further effect.

And, finally, there is the level of body-embedded expressions or, as $\mathrm{H}$. Plessner showed in his lecture "On the hermeneutics of non-linguistic expressions" (Seminar held during the VIII German Congress on Philosophy in Heidelberg, 1966), the relationship between the grammatical sentence and the latent sense of the expression can become symptomatically represented. ${ }^{3}$ The body-embedded expression can legitimize, reinforce, yet also negate and deny, or ironically underline, an utterance as well as signalize its obstructive, deceptive or self-deceptive components.

"In connection with words and acts, expression serves as an indication of how seriously something is meant, whether the communicating subject is deceiving itself or others, to what degree it wants to or may identify itself with an actual expression of its own life, and how broad is the spectrum of connotation, concealment, or contrary intentions" (Habermas 1989: 167).

It becomes clear here that understanding primarily focuses on the structure of ordinary language, i.e. the mutual interpretation of speech and action in intersubjectivity. Ordinary language does not pursue the syntax of a pure or a formal language.

"The grammar of language games in the sense of a complete structure of conduct regulates not only the combination of symbols but also the interpretation of linguistic symbols through actions and expressions" (Habermas 1989: 168).

As opposed to pure, formal languages, an ordinary language is in a position to very simply reflect upon itself and to change to the level of formal language and back again. It is the ultimate meta-language. Without exception, all "pure" (formal) languages had to develop directly or indirectly from it. No human is born proficient in the scientific language, i.e., a formalizable syntactic-semantic system.

\footnotetext{
${ }^{3}$ The systematic study and medical treatment of physical symptoms as a non-verbalized, subconscious expression of a mental affliction was a domain of Thure von Uexküll, the founder of modern psychosomatics. Pioneering he recognized, that the mechanistic apparatus-medicine neither theoretically nor practically could please human needs and so he developed the „Humanmedizin“. Beyond this, he also introduced a revolutionary perspective - a semiotic foundation for all natural sciences (Uexkuell 1989)
} 
Ordinary language is the only language capable of functioning as its own meta-language. It can even interpret itself because it stands in a complementary relationship with the non-verbal forms of action and expression:

"We can talk about actions and describe them. We can name expressions and even make language itself the medium of experiential expression, whether phonetically, by exploiting the expressivity of intonation, or stylistically, by representing in language itself the relation of the subject to its linguistic objectivations. All ordinary language allows reflexive allusions as to what has remained unstated. Many categories of allusions of this sort have become conventions, either in subsystems such as wit and poetry, or in stylized linguistic forms such as irony, understatement, and imitation, or in established figures of speech such as the rhetorical question, the euphemism, etc." (Habermas 1989: 169).

Against the backdrop of interrelationships between language use, action and body-embedded expression in the framework of the conditions of successful communication, we humans reach something along the lines of a self-interpretive self-understanding as subjects and objects alike.

\subsection{Can Natural Scientists Understand?}

Natural scientists are also capable of understanding, yet are unable to adequately explain or reconstruct this process of understanding. Based on methodological considerations alone, this level is denied to the objectifying (formalizable) language use and is therefore entirely inaccessible: Methodologically, they cannot transcend the observer perspective of the solus ipse thinker of Cartesian paradigm. ${ }^{4}$

"The monological approach preordained certain ways of posing the basic problems of thought and action: subject versus object, reason versus sense, reason versus desire, mind versus body, self versus other, and so on" (McCarthy 1984: ix)

The "pure", formalizable languages of the natural sciences, which attempt to bridge the difference between observation and theoretical language in (reproducible) experimental set-ups, cannot reflect on this pure language in a pure language. They require a meta-language, which in turn requires a meta-metalanguage, ad infinitum.

And even if we take the route (which can by no means be legitimized) and transfer the selfresponsibility of our own reason to a higher-ranking systems feature, then we would, in a systemstheoretical calculation, eliminate all subsystems of deep-grammatical levels of meaning and interaction and declare them to be non-existent. Nonetheless, even the systems theoretical construction is possible solely based on a formerly learned speech- and action-competence in ordinary language (Witzany 1995, $2000,2002 \mathrm{a} / \mathrm{b})$. Systems theory in most variations presents

"... systems introduced at a level higher and more general than that of actors and linguistically mediated interactions. Actors and interactions can then be reinterpreted as psychological and social systems, each of which forms an environment for and reciprocally observes the other. Systems theory (...) has, however, had to pay a price for its objective turn. This approach cuts itself off from any intuitive knowledge of the lifeworld and its members. (...) Yet society, woven from a lattice of linguistically-mediated interactions, is inadequately conceptualized in the shape of an external nature accessible only to observation" (Habermas 1994: 64).

\footnotetext{
${ }^{4}$ Paradigmatic objectivism/physicalism/naturalism led to a dead end in the form of the linguistic turn and from a 3-leveled to a 2leveled (syntactic-semantic) semiotics: "As a science, semiotics has the same scientific structure - terminologically and methodologically - as physics and biology" (Morris 1945: 512).
} 


\subsection{What does Biology as an Understanding Social Science Want?}

The social science analysis of human understanding shows that sign use and rule-governed signmediated interaction can arise only through participation in social lifeworlds or in contexts of interacting individuals-in-populations. From the perspective of this understanding and self-understanding of human communication, biology as an understanding social science can also study non-human individuals-inpopulations. There, it will not find the rationality of human communicative action, but the possibility to understand the social lifeworlds of non-human organisms in describing sign-mediated interactions. ${ }^{5}$ Once we are also able to describe the rules that sign use follows, then we have really begun to understand the communication process.

In a biology that functions as an understanding social science, the task is to understand the communicative interrelationship of sign processes, actions and body-embedded expressions, i.e., to describe the rules of a well-coordinated practice of life. Intermeshing sign processes and practical action between individuals is the starting point for a biology that can understand at the social science level: And in this well-coordinated practice of life we find the contexts for description. Understanding functions here as describing (not explaining) (Vossenkuhl 1998) the context-dependent use of signs interconnected with actions and body-embedded expressions. This description also centers on the actional aspect or the expressional one. In describing this interactional practice, we may understand (or even misunderstand) the rules that underlie the sign-mediated interactions. ${ }^{6}$

In opposition to biology as a natural science and present biosemiotics, biology as an understanding social science has already implemented the pragmatic turn in its self-foundation and self-justification: By reflecting upon the intersubjective-communicative character of thought, experience and research, the pragmatic turn overcomes the subject-object split and its methodological consequences, solipsism and objectivism.

"Referring back to the rules of communicative action provides an opportunity to answer questions of evolutionary logic and dynamics as questions of interaction logic and dynamics. Evolutionary history could then be understood as a developmental history of interaction semioses. If we could further establish that the rules governing evolution are equivalent to the communication rules behind the history of interaction, then we can justify the view that rule-governed behavior is a factor not only in humans, but especially in non-human living nature" (Witzany 2000: 13).

Biology as an understanding social science is then in a position to question the empirical-objectifying and therefore also the behavioristic study of semioses between organisms. Moreover, it can describe biological as biosemiotic observations with respect to the communication rules and the history of interaction of the social lifeworld of the respective individuals-in-populations. One special focus for this may be animal sociology and plant sociology (Dierschke 1994), but naturally also archae- and eubacterial semiotics, zoo-, phytae- and fungi-semiotics. This may be the supplementary function of biology as an understanding social science and traditional biology, respectively biosemiotics. The task of this biology as an understanding social science is to learn to understand the ordinary languages of non-human organisms by describing their sign use, action and body-embedded expression, describing the underlying

\footnotetext{
${ }^{5}$ Clearly, the communicative organisation of social lifeworlds differs between humans, animals, fungi, plants, and microorganisms. Every organismic kingdom, every species and every genus has a different code, signal media and body-embedded expressions, so that, at first glance, one can hardly detect any analogies at all. Thus, intraorganismic communication in all organisms, for example, functions almost exclusively with signal molecules along signalling pathways, i.e. chemical molecule codes are involved. A pragmatic philosophy of biology, or a biosemiotic perspective, rapidly enables the commonality of language and communication at all levels of living nature to be identified, namely that every use of signals follows grammatical, semantic and pragmatic rules, and e.g. that the comparability between the genetic code and natural language becomes clearer (see also Pattee 2005: 298-299).

${ }^{6}$ This is the decisive difference between an understanding biology and hermeneutics as developed by Gadamer. He founded hermeneutics ontologically ("Hermeneutik der Faktizität") as the ultimate and the only possibility for an existential relationship between humans and lifeworld and not as description of the rules underlying sign-mediated interactions in historically different contexts.
} 
grammatical, semantic and pragmatic rules. This may begin with primates, followed by other highly developed mammals such as cetaceans or elephants and many species of domestic animals and songbirds, extending to plants, fungi, protoctists down to the level of sign-mediated interactions between bacteria. $^{7}$ And this doesn't end at the understanding of the ordinary language of the rule-governed signmediated interactions in cells, such as RNA processing induced by proteins or higher order regulatory functions of non-proteincoding DNA (Witzany 2005).

Lotman and Hoffmeyer (Hoffmeyer 1996) have coined the word "semiosphere" to denote that, much like the biosphere, there is a sphere of sign processes with the full range of levels and phenomena. The concept of biology as an understanding social science investigates the concrete social lifeworlds of species and genera that share a specific repertoire of signs and rules. All organisms above the level of bacteria are composed of eukaryotic cells, which are now recognized as representing associations of early bacterial organisms (Margulis 1996, 2004, 1999, Margulis et al. 2000, Margulis and Sagan 2002), perhaps historically the first genetically fixed sign-mediated social lifeworlds. Therefore, to me, an approach involving the social lifeworld appears to be more appropriate than the term semiosphere, which attempts to unite biosemiotics with the natural sciences and their objectivistic $3^{\text {rd }}$-person perspective.

Biology as an understanding social science recognizes physical-mathematical explanatory models and the overall system of sciences as one of many other elements of a comprehensive life context and is, therefore, anti-reductionistic, anti-mechanistic and even anti-materialistic.

Linguistic communication, action and body-embedded expression are primarily phenomena that are accessible for subjective perception and are not the object of observation methods rooted in the natural sciences. This is because objectivizing, exclusively explanatory and behavioristic definitions of language and communication in principle cannot formalize, i.e., quantify by measurement, the differentiation of superficial and deep grammar, of locutionary, illocutionary and perlocutionary speech acts, action and body-embedded expression.

One experience in the framework of understanding is that it is "(...) not a subjective process of becoming conscious of fundamental organic states. Instead it is relative to intentions and is always mediated by an act of understanding meaning" (Habermas 1989: 147). Therefore, the transmitter-receiver model and its implications of encoding and decoding information as used in numerous disciplines represent classical solipsistic approaches that are in principle insufficient to fully explain the key features such as linguistic action, simultaneous mutual understanding of identical meanings, the reciprocal interpretation of speech, action and body-embedded expression as being characteristic for ordinary languages.

Biology as an understanding social science does not strive to understand biological processes in order to make them more amenable to the methodologies of natural sciences or to make them available for technological-scientific progress. Social lifeworlds, in particular, are the study objects of a biology as an understanding social science and they enable progress towards an integrative natural science, which has the potential to overcome the jumble of different biological subdisciplines. Its primary interest is progress in understanding living nature, as a prerequisite for appropriate actions by human populations towards non-human living nature, and not primarily the technical subjugation and exploitation of knowledge about biological processes. We need to remind ourselves that the current orientation of biological sciences

\footnotetext{
${ }^{7}$ Humans are able to learn the DNA/RNA and protein language by analyzing rule-governed sign-meditated interactions between proteins and DNA. Some examples for other understanding options: hox genes and their rules of expression, immune system (intraorganismic communication), rules of sign using bacterial communities (quorum sensing); symbolic and analog languages and dialects of the bees; communicative interactions between chimpanzees (Jane Goodall "participating observation"), gorillas (Diane Fossey), orangutans (Biruté Galdikas), elephants (interorganismic communication), between the lion female "Kamuniak" and antelope kids (phonetical, actional, expressional) in Samburu Nationalpark/Kenia in 2002; cooperating fishing techniques between fishermen and dolphins as a tradition of native tribes in eastern Africa, etc. (metaorganismic social competence).
} 
continues to be purely a research of conditions. Rather than asking what something is, it asks what the conditions for its origins are. It takes this course of inquiry because, by determining these conditions, it itself gains the ability to intervene in the course of events. The interest behind knowledge in this orientation is to control nature and to (commercially) exploit it. To know something, as Thomas Hobbes wrote, is "to know what we can do with it when we have it."

The knowledge and human interests of scientific research in biology as an understanding social science is, therefore, not an objectivistic one, but an emancipative one from reductionistic materialism. "The lifeworld functions as a counterconcept to those idealizations that constitute the object domain of the natural sciences in the first place" (Habermas 1994: 68).

Therefore, biology as an understanding social science focuses on founding a completely different relationship between humans and non-human living nature; one that focuses not only on "Umwelt" but primarily on "Mitwelt" ${ }^{8}$ (co-world); one that is characterized by respect and recognition, that is rationally founded, and that does not definitively rule out the integration of spiritual experiences both of inner and outer nature.

\section{3. "Mitwelt" Supplements "Umwelt"}

"From biosphere to semiosphere to social lifeworlds" shows that a comprehensive understanding of language and communication can only be achieved by employing a pragmatic theory of action. It provides us with an understanding and self-understanding of human and non-human, rule-governed sign-mediated interactions that other theoretical frameworks and scientific models which are founded on an objectivistic paradigm (physicalism/naturalism) are unable to impart.

In particular, the term "social lifeworld" designates the interorganismic or "species-specific" communication in which organisms are primarily involved due to their evolutionary history. Interorganismic communication was long postulated to be the sole or exclusive form. Today, we are in the early phase of recognizing that intra- (in and between cells) and metaorganismic (transspecific: symbiotic, parasitic) ${ }^{9}$ are no less important.

In studying living nature, the term social lifeworld (as the realm of interorganismic communication) should become part of the Mitwelt-concept because Mitwelt contains all those communication partners of interacting organisms, with whom communication processes can be carried out.

Only in the last decade has the focus shifted to the decisive role of symbiotic interactions in these processes (Zook 1998). At the same time, the pragmatic communication concept has distinguished itself from the ontosemantic or mere syntactic communication concepts, which hold the sign process itself to be responsible for constituting meaning (Witzany 1993 b, 1995).

\footnotetext{
8 "Die Welt des Daseins ist Mitwelt". (Heidegger 1979: 118); In contrast to the "Umwelt" concept, a biosemiotic "Mitwelt" concept integrates the intersubjective-communicative character of thought, experience and research being central for its foundation and justification and, therefore, provides the subject-object split and its methodological consequences, solipsism and objectivism (physicalism, naturalism). The Mitwelt concept also creates an opportunity to change the self-awareness of human beings as participants of a global communicative community within a linguistically and communicatively structured and organized living nature.

${ }^{9}$ Mutualism: non-obligatory or temporary relationship between two populations that benefits both populations

Symbiosis: obligatory relationship between two populations that benefits both populations

Amensalism: association which is detrimental to one species and neutral to the other

Commensalism: association in which one organism is benefitted and the other organism is neither benefitted nor harmed

Competition: association between two species, both of which need some limited environmental factor for growth and must share the growth-limiting resource

Predation: interaction between organisms in which one organism captures and feeds upon another organism

Parasitism: interaction between organisms in which one benefits and one is harmed.
} 


\subsection{Communication Processes are Rule-Governed Sign-Mediated Interactions}

The Mitwelt concept supplements the Umwelt concept because the latter does not differentiate sufficiently between the influences on those organisms that are not components of communication processes and rule-governed sign-mediated interactions. The Umwelt concept subsumes rule-governed sign-mediated interactions in a coding-decoding mechanism (within an objectivistic-solipsistic transmitterreceiver explanatory model) which is conducted by sensory organs according to criteria that are exclusively physiological and therefore underlie natural laws in a strict sense. The Umwelt concept is well suited to describe physiological interactions between living beings and non-living matter, but not communication processes. Mitwelt therefore exists whenever rule-governed sign-mediated interactions are involved. It makes little sense to refer here to social Umwelt because no decicive distinction is made between living and non-living influences.

Whenever communication occurs, the signs that are used are related to one another in a rule-based manner that we can term (a) grammatical, i.e. the signs underlie rules governing combinatory arrangement that can either be followed or broken. If the combination of signs follows the rules, then communication using this sign repertoire can be successful; if the rules are broken and the signs are arranged in a manner that does not conform to the rules, then the message is deformed or incomprehensible.

The same holds true with (b) the pragmatic rules. They govern the mode of encounter between the sign users. Allelopathic reactions in the root zone of plants, for example, are there to maintain the sovereignty of lifeworlds within the root zone (rhizosphere): The individual sphere of a particular plant root, including its symbiotic interaction partners, requires certain basic conditions to survive and thrive. If these are compromized, a reaction is triggered that makes it impossible for other, competing roots to penetrate this habitat (Dunn and Handelsman 2002, Dessaux 2005, Walker et al. 2003).

These pragmatic rules then also determine (c) the meaning of the used signs in the communication processes: The specific situational context of the interactions decides on the context of use of the sign(molecules) and thus on their meaning. Only a limited number of chemical messenger substances is available to for example maintain and simultaneously conduct the communication between root cells, between root cells and microorganisms, fungi and insects, i.e. the same molecules - in different molecular sequences or molecular densities- are used to compose a variety of messages (Walker 2003).

We should not conclude that the sign process itself is the central element. Nor should we emphasize the metaphysical dimension of the signs as independent or even vital reality: after all, without the sign users, no signs are used. This would lead to the reductionistic fallacy, wherein the quantification of signals is mistaken for the message content or for the interaction process it conveys. This is evident in studies that attempt to understand the content of a signalling-pathway message by algorithmically-statistically measuring the quantity of particular messenger substances (Searls 1992, 2002, Mantegna et al.1994, Ji 1999, Gerrish 2001, Waugh et al. 2002, Skusa 2003). This would be equivalent to trying to understand the form and depicted content of a painting through physico-chemical analyses of the applied colors.

\subsection{From the Anthropocentric, to the Biocentric, to the Symbiocentric View of life}

Even today, many philosophers and other anthropocentrically oriented scientists hold that language and communication are actually used only by humans. Advances in microbiology and plant neurobiology, however, have demonstrated that this is a very restricted point of view (Trewavas 2001, 2003, Perbal 2003, Baluska et al. $2004 \mathrm{a} / \mathrm{b}$, Ben Jacob 2004). It is founded on an antiquated misconception from an era in which science was largely founded and justified based on metaphysics. Language and communication were long held to be a privileged gift of God to his favorite creation, human beings. These metaphysical 
foundations lost their dominant position once it became clear that living nature in its entirety - and not only humans - talk and communicate, which doesn't need necessarily only phonetically mediated signals/symbols but also chemical molecules which may function as signs.

Humans represent only one of many million species, and our fate is directly or indirectly dependent on those species. Throughout their lives, organisms exhibit a symbiotic interdependence with members of other species.

Today we know that, in living nature, practically all forms of behavioral coordination between conspecifics involve communication processes whose signs follow grammatical, semantic and pragmatic rules. Adherence or non-adherence to these rules determines the success or failure of the communication process.

Sometimes, however, non-adherence to regulative or constitutive rules can be determined without communication failure, namely when a new rule replaces an existing one: for example when an innovative rule of sign use is created that enables new communication processes that, in turn, lead to new behavioral coordinations or, in the genetic realm, to new codings or sequences that can also be expressed phentotypically.

\subsection{The Logos of the Bios: 3 Levels of Rules on 3 Levels of Communication}

In contrast to mechanistic or materialistic paradigms, which orient biological research processes, ${ }^{10} \mathrm{a}$ biology as an understanding social science examines the 3 levels of rules of sign use in 3 levels of communication: Accordingly, there are (a) grammatical, (b) semantic and (c) pragmatic rules of sign use in (1) communication processes in and between cells (intraorganismic communication), (2) between members of the same biological species (interorganismic communication) and (3) between members of different species, genera, organismic kingdoms (Witzany 1993 b, 2000).

As organisms are usually concurrently involved in all three communication levels throughout their lives, the Mitwelt-concept is useful in describing ongoing communicative reality.

\subsection{Types of Communication Within and Between Organisms}

In describing the rules of sign use, an understanding biology, therefore, focuses on communication forms in and between all organisms and organismic kingdoms. In the real lifeworlds, however, organisms participate in a very broad array of communication processes due to the omnipresent symbioses. ${ }^{11}$ The full range of potential and actual sign-mediated interactions in and between organisms represents the diversity of life on our planet. Defining Mitwelt along the lines of the 5 organismic kingdoms yields the following potential interaction categories for communication processes. This excludes the cell-cell communication levels in eukaryotes, for example cell-cell communication in plants (Fleming 2005). The references in parentheses are not exhaustive, but only arbitrary examples:

Bacteria communication: Bacteria-bacteria (Dunn and Handelsman 2002), bacteria-plant (Sharma et al. 2003), bacteria-animal (McFall-Ngai 2002), bacteria-fungi

Animal communication: Animal-bacteria (Hooper et al.1998, Douglas 1998), animal-animal (Frisch 1971, Seeley 1995), animal-fungi, animal-plants (Frisch 1971)

\footnotetext{
${ }^{10}$ They can be recognized based on the tacked-on mechanistic attributes such as "-machinery", "-mechanism", "-apparatus".

${ }^{11}$ Interestingly, the relationship between endo- and ectosymbioses consists of the fact that the genetic make-up of an endosymbiont continuously decreases whereas that of ectosymbionts clearly increases. Because the host organism dominantly acquires the additional capabilities of the endosymbiont, its genome is reduced to the bare essentials, whereas the ectosymbiont integrates the reciprocal symbiotic interaction competence to expand its original genetic make-up (Batut et al. 2004, Kowallik 1999).
} 
Fungi communication: Fungi-bacteria (Romano and Kolter 2005), fungi-fungi, fungi-animal, fungi-plant (Kahmann and Basse 2001)

Plant Communication: Plant-bacteria (Teplitski et al. 2000, Fox 2004), plant-plant (Estabrook and Yoder 1998, Engelberth et al. 2004), plant-fungi (Hirsch et al. 2003, Imaizumi-Anraku et al. 2005), plant-animal (Bloom and Holbroock 2001)

What is the difference between rule-governed sign-mediated interactions in bacteria-plant and plantbacteria communication: It is the organisation of the answer of an organism, because the signalling pathways in producing appropriate messenger substances are different for a plant and a bacterium, even when an endosymbiotic bacterium or even fungi produces plant hormones (Dessaux 2005). Depending on the focus of the investigation, the pathway lies in one or the other direction.

When biology, as an understanding social science, examines multilevel communication - and such communication is the global, everyday reality - then the study can focus on parallel rule-governed signmediated interactions in Drieschke 1994 between bacteria-fungi-plants-animals, for example in the rhizosphere.

\section{Mitwelt: Examples}

Here, I present a few selected examples from the realm of bacteria and the realm of plants in order to demonstrate the close interrelationships of social lifeworlds with their Mitwelt.

\subsection{Intra- and Intermicrobial Communication}

Today we know that bacterial interaction communities can communicate among themselves and identify how large they are. This allows them to coordinate their behavior so that they can live together with other bacterial communities (Kaiser and Losick 1993, Fuqua et al. 1996, Losick and Kaiser 1997, Bassler 1999, Schauder and Bassler 2001, Schauder et al. 2001).

The rule-governed sign-mediated interactions known as "quorum sensing" contain two different, complementary levels of communication (Federle and Bassler 2003). The bacteria determine their quorum by releasing signal molecules into the surroundings. Once a particular threshold value is passed, the messenger substances immediately return to the microorganisms, "turn on" certain genes, "turn off" others, and, thus, alter the behavior of the bacteria (Fuqua et al. 1996). In some cases the microbes release toxins and destructive enzymes, in other cases they coat themselves in a mucus film that protects them against antibiotics or disinfectants (Sharma et al. 2003).

Communication processes enable bacteria to coordinate their population behavior and therefore to act like a multicellular organism (Schauder/Bassler 2001).

The range of behaviors is large, for example interactions with one another (Montana State University, 1999), symbioses with eukaryotic hosts, viral infections, antibiotic production processes or biofilmorganization. Interestingly, communication within a species (interorganismic) is conducted with one language, that with other species (metaorganismic) in another language. The metaorganismically used linguistic signs have been described as being universal for almost all bacteria species (bacterial esperanto). Researchers, therefore, refer to multilingual bacteria (Schauder/Bassler 2001).

Thus, the communication processes of multiple microbial communities (biofilms), for example in the oral cavity of humans (Kolenbrander et al. 2002), show different forms of cell-cell communication, allowing several billion representatives of 500 different species (!) to coordinate their behavior and survive, at least between episodes of oral hygiene, which pose a real threat to these cultures. "The various species within oral biofilms function as independent, discrete constituents" (and) "as a coordinated community that uses 
intra- and interspecies communication." (Kolenbrander et al. 2002: 486). The various species continuously compete and cooperate with one another to establish a stable community that is tolerable for all 500 species. Some researchers report that biofilm interactions promote altruism (Kreft 2004).

The colonization of suitable surfaces varies temporally: some bacteria species are more successful initially than later on denser interactional space, others are initially less successful and later more so (Kolenbrander et al. 2002).

Competing bacteria populations have developed strategies to disrupt these communication processes, for example by destroying the chemical signal molecules or by producing autoinducer-antagonists that can mask the communication levels; even autoinducer mimicry is known. Such tactical behavior has been reported not only in inter-generic interactions but also in inter-kingdom interactions. Although the tactics of the populations differ considerably, they have one thing in common: the coordinated behavior of social groups enables survival and reproductive success (Velicer 2003).

As opposed to competing communities, cooperative ones employ tactics that mutually support one another and that promote the communication processes.

\subsection{Microbe-Animal Communication}

Interactions are either symbiotic or parasitic here as well. In the last few years, research has made great strides on these communication processes. For example, infectious bacteria are now known to be capable of altering the intracellular communication of the animal's host cells and therefore circumvent the defense strategies of the host immune system. The evolutionary development of the animal kingdom was strongly influenced by symbiotic and endosymbiotic interactions between bacteria and animals (Douglas 1998, McFall-Ngai 2002).

In symbiotic communication processes, bacteria help animals to survive by fulfilling numerous supportive functions, especially in digestion and metabolism, without which the animal organism could not survive (Hooper et al. 1998).

\subsection{Microbe-Fungi Communication}

Rule-governed sign-mediated interactions here also involve symbiosis or parasitism. Research on these communication processes has yielded significant new insights. Microbe-fungi communication is most highly differentiated in the root zone of plants: here, it involves a multilevel communication, i.e., both intraand metaorganismically with numerous species from the same and different organismic kingdoms; this requires a high intraorganismic communication competence (Walker 2003, Bais et al. 2004).

\subsection{Microbe-Plant Communication}

The communication between microbes and plant cells is either symbiotic or parasitic (Keyes 2000). The symbiotic interactions represent an indispensible supplement and support for both the above- and belowground plant parts (Estabrook and Yoder 1998, Teplitski et al. 2000, Dunn and Handelsman 2002, Dessaux 2004). The communication process in the root zone is generally intra-, inter- and metaorganismic and requires a high communicative competence in order to be successfully interactive on all three levels and to distinguish messenger molecules from "noise" (Federle and Bassler 2003, Hirsch et al. 2003, Sharma et al. 2003).

Multilevel communication proceeds simultaneously between microbes, fungi, insects and root cells of the plant. Plants depend on the ability of roots to communicate with microbes (Bais et al. 2004). The bacterial communication takes place between different bacteria species in the soil around the plant, 
between soil bacteria and endosymbiotic bacteria of the plant, between bacteria and fungi (mycorrhiza) and between bacteria and roots. These rule-governed sign-mediated interactions are parallel processes (Bais et al. 2004). Here, root communication by the 3 different forms of root cells produces ca. 100000 different compounds (Walker et al. 2003). The complexity, learning ability and memory of the rulegoverned sign-mediated interactions in the root zone are reminiscent of those in the brain (Trewavas 2003).

\subsection{Plant-Plant Communication}

Plants represent a major success story in evolution and are the most recent organismic kingdom. Higher plants make up $99 \%$ of the eukaryotic biomass on our planet. Of this, approximately $84 \%$ are trees. At the same time, this success story also reflects the success of multilevel communicative actions by plants in their intra-, inter- and metaorganismic stages: it represents a crucial dependency on successful communication with microbial communities, with fungi (especially in the rhizosphere), with animals (especially with insects) and, in parallel, the complex multilevel brainlike communication processes in and between cells, tissues and the whole body (Trewavas 2003).

Plant scientists formerly thought of plants as automatons. Research into the multilevel communication of plants revealed activities like learning, memory, individuality and plasticity as an expression of so-called "plant intelligence", which is no metaphoric term (Trewavas 2003). Plant research in the past 5 years has also revealed that the old dichotomy of chemical vs neuronal-electric communication was a misinterpretation. Today we know that $99 \%$ of neuronal communication is based on chemical messenger substances, and that electric action potentials serve merely to maintain the transport of messenger substances along long neural tracts (Trewavas 2003). Based on this knowledge, the catchword in the $21^{\text {st }}$ century will be plant neurbiology rather than plant physiology.

The communication between plant tissue and the plant cells is exceptionally complex and encompasses nucleic acids, oligonucleotides, proteins and peptides, minerals, oxidative signals, gases, hydraulic and mechanical signals, electric signals, fatty acids, oligosaccharides, growth regulators, amino acids, numerous secondary products, simple sugars, and many other as yet unstudied aspects. These intraorganismic communication processes take place alongside (a) interorganismic (Yoder 1999) and (b) metaorganismic processes with insects and fungi as well as bacteria colonies on the plant surface and particularly in the rhizosphere (Walker et al. 2003, Bais et al. 2004).

As is the case in communicative interaction in general, the pragmatic situational context of the signusing individual or the individual involved in rule-governed sign-mediated interactions determines the concrete meaning of the message: the same signals elicit different responses depending upon whether a plant, a tissue, or a cell receives it. Because plants are constantly in a developmental stage, communication is the central and most important organizational element. Because growth regulators overlap and multilevel communication is commonplace, scientists note that "plants can be best viewed as more like a democratic confederation in their control structure rather than an autocracy as occurs in animals, controlled by an all-embracing nervous system" (Trewavas 2003: 10).

Pragmatic rules of sign use may be an approach for integrating different questions of "how many varieties of behavior can be constructed with a limited number of tissues", or "does partial independence in the behavior of individual growing tissues change a holistic view of plant intelligence" (Trewavas 2003: 10). 


\subsection{Cell Theory vs. Cell Body Theory}

Classic cell theory assumes that all eukaryotic organisms are composed of cells: The cell is the smallest unit of life, and all animals and plant tissues consist of such cells. All cells originate from previously existing cells. Brain tissue also has a cellular structure. The same holds true for prokaryotic and single-celled eukaryotic organisms.

On the other hand, supracellular structures in higher plants do not conform to this picture and they are incompatible with traditional cell theory (Baluska et al. $2004 \mathrm{a} / \mathrm{b}$ ). Plant cells are not separated from one another physiologically - they can be interpreted as "communicative cytoplasms" (Baluska et al. a 2004: 10). The cytoplasms of cells are connected with one another via plasmodesmata (cell-cell channels) and endoplasmatic reticulum into supracellular structures joined by a plasma membrane. Larger molecules such as proteins and RNAs can also be exchanged between the cells, and a mass flow of smaller molecules is possible.

In contrast to cell theory, plant cells are neither physically separated from one another nor structurally independent. Uniform areas of the nucleus and attached microtubules are enclosed in cytoplasmatic regions. The cell body theory (Baluska et al. $2004 \mathrm{a} / \mathrm{b}$ ) refers to these regions as cell body following D. Mazias' theory about these units. The cell bodies are, in fact, the elementary units not only of eukaryotes but also of life in general.

The microtubules are important in maintaining the distances between nuclei in the multi-nucleus cytoplasmatic community. This also holds true in a number of animals. The authors demonstrate that in the nucleus itself the most important signalling pathways are split between the cell body (which organizes the exocytic secretory pathway) and the cell periphery apparatus. The endoplasmatic reticulum, Golgi apparatus and secretory vesicles belong to the cell body. In contrast to the cell body, the cell periphery apparatus organizes the endocytic secretory pathway and consists of endocytic vesicles, recycling vesicles, early and late endosomes (Baluska et al. a 2004: 18).

The two differing competence centers, (a) the actin-based cell periphery apparatus and (b) the tubulinbased cell body, point to the union of two protocells with different capabilities (Cavalier-Smith, 2002). Accordingly, an active, motile, tubulin-based protocell united with a larger, passive, actin-based protocell (Dolan 2002). The tubulin-based protocell, with its cilia, become the actual nucleus, the actin-based protocell became the cell periphery apparatus. Only later were plastids and mitochondria integrated. "The centrosomes of the nucleus may be highly reduced endosymbionts retaining only centrosomes and microtubules" (Baluska et al. 2004 a: 13).

The development of the plasma membrane along with its related structures can be initiated de novo by the cell body. This can occur occasionally, for example after injuries, but also on a rule-governed basis during cytokinesis and meiosis. The cell body cannot be created de novo, but exclusively by an already existing cell. Accordingly, the cell body represents the smallest and most elementary self-reproducing unit of eukaryotic life (Baluska et al. 2004a, b).

The cell body theory is also a very interesting concept because it can offer a stringent explanation about the function of non-coding DNA. Accordingly, the non-coding DNA controls the nuclear structure based on its ability to control the internal nuclear structure and to control the ability of those nuclear proteins that conduct tubulin-polymerized activities. Non-coding DNA can, therefore, be interpreted as nucleoskeletal DNA. 
"From the point of view of cell body, there is no difference between coding DNA and non-coding DNA; both are predicted to interact, directly or indirectly, with the sequestered nuclear proteins" (Baluska et al. 2004a: 21).

Non-coding DNA becomes an important feature behind the interconnection of DNA-based nuclear chromatin and the tubulin-based cytoskeleton. "This feature allows the cell body to couple genomic information (encoded within DNA sequences and handed over to RNA molecules) with epigenetic information (embodied within the inherent physical properties of DNA structures, which can store and propagate this information via complex DNA-protein and protein templating processes)" (Baluska et al. 2004 a: 21).

\section{Evolution by Metaorganismic Rule-Governed Sign-Mediated Interactions: Serial Endosymbiotic Theory (SET)}

Lynn Margulis introduces an interesting theory: The higher development of species, genera and organismic kingdoms on our planet took place beyond the bacteria, and involved the merging of different bacteria with differing capabilities; the eukaryotic cell as the basis for all eukaryotic organismic kingdoms originated through merging of archae- with eubacteria (Margulis 1996, 1999, 2004, Margulis et al. 2000, Margulis and Sagan 2002, Stechmann and Cavalier-Smith 2003).

The differentiation of bacteria groups with very different capabilities within the first 2 billion years after the origin of life led to an enormous bacterial gene pool. 10000 different species have been described. This also led to forms of life that accumulated such diverse capabilities. Examples include anaerobic and aerobic, photo- and chemosynthetically active, acido-, thermoacidophilic, halophilic, methane- and oxygen-producing, osmotic, lipophilic forms, etc. We know today that bacteria can exchange these genetically coded abilities (horizontal gene transfer - HGT), accumulate them and multiply their competences. Four such competence bearers ultimately joined into a new cell form, the eukaryotic cell (Margulis and Sagan 2002).

\subsection{Symbiosis as a Step to Endosymbiosis as a Step to Symbiogenesis}

Margulis refers to the term symbiogenesis as coined by K. S. Mereschkovsky and I. Wallin. The authors argue that new tissues, organs, organisms and species arise by entering into long-term, permanent symbioses. Bacteria were permanently incorporated into animal and plant cells as plastids and mitochondria (Searcy 2003). Margulis proved that most of the DNA we find in the cytoplasm of animals, fungi and plants originally stemmed from bacteria that had developed into organelles, and not from mutation processes or genetic drift.

Symbiogenesis enables life forms to acquire entire organisms along with their genetic complement (representing a form of Lamarckism in acquiring characters). Symbiogenesis unites individuals into larger individuals consisting of many units (Margulis 1999).

One important aspect is that those gene carriers are located in the cell structures (organelles) but outside the nucleus of a eukaryotic cell. Margulis notes with interest that some genetic factors in plants and animals are distributed throughout the cell, i.e., they are not only determined by the genes in the nucleus. She points to experiments that clearly demonstrate the influence of plastids and mitochondria on heredity. These extranuclear parts, with their unique heredity, are remnants of formerly free-living bacteria. This represents a double hereditary system involving (formerly independent) cells inside other cells (Margulis 1999). 
She also reports on an experiment conducted by Tracy Sonneborn, who surgically removed cilia along with a part of their bases from Paramecium and re-implanted them - rotated by 180 degrees - on the cell surface. These cilia were reproduced over 200 generations just as the scientists had altered them, showing that acquired characters can in fact be inheritable (Margulis 1999).

The SET is a theory on the union or merging of cells with different histories and different capabilities. The theory states that symbiogenesis combines individuals into larger individuals consisting of many units and enables life-forms to acquire entire organisms including their genetic make-up. Symbiogenesis explains the development of an individual based on the interactions of formerly independent entities. (Margulis 1996, 2004, Margulis and Sagan 2002).

According to Margulis, the more complex eukaryotic organisms are both, surrounded by bacteria and are evolved from bacteria. This new perspective changes the viewpoint that evolution is a constant bloody battle between organisms. Accordingly, life spread across the globe not through struggle but by linkage. Life-forms did not become more complex by eliminating competitors, but by acquiring capabilities.

In a phase lasting 2 billion years, bacteria initially transferred their genes to other bacteria from which they differed considerably. The bacterium that acquired genes using this strategy was suddenly able to perform functions not coded in its own genetic material. Bacteria can exchange genes very quickly and also reversibly. As opposed to other life-forms, bacteria have genetic access to the diversity contained within their entire organismic kingdom.

\subsection{Integration of 4 Different Competences}

Margulis thesis on the decisive development of cells with true nuclei is a "merging" of thermoacidophilic bacteria (sulphur reduction/fermentation) with Spirochaeta (motility), alpha proteobacteria (oxygen respiration) and Synechococcus cyanobacteria (photosynthesis). The crucial factor for postulating endosymbiotic processes in the development of novel organisms was the observation that mitochondria and plastids never arise de novo, but always through division and separation (Margulis 1999, Kowallik 1999). Mitochondria live within our cells, but reproduce themselves at times and by means that differ from those of our own body cells. Without mitochondria, however, neither plant nor animal cells can breathe and both die.

The origin of a new species, along with the loss of the formerly independent individuals, involves merging different bacteria genomes to a single DNA text. ${ }^{12}$ This does not proceed via an altered aggregate status but requires a recombination that incorporates the foreign DNA text - the external becomes an internal.

\subsection{Horizontal Gene Transfer in Bacterial Exchange Communities}

The strategy by which bacteria are assumed to have merged their genomes is Horizontal Gene Transfer (HGT) (Wagner et al. 1999, Xie et al. 2004, Wolf 1999, 2000, Timmis et al. 2004). This led to true exchange communities (Jain et al. 1999, 2003). HGT promotes genetic diversity by distributing genetic content beyond species borders. HGT therefore circumvents the slow and stepwise new development of genes by rapidly inserting available genes into existing genomes. This, of course, is only valid in organisms capable of rapidly exchanging or incorporating genes. Exchange communities are similar with

\footnotetext{
${ }^{12}$ With his theory, Carl Woese indirectly confirms the SET: In the world of protists there was no evolution involving common ancestry in the sense of a linear succession of generations, but rather evolution through (gene) exchange and horizontal gene transfer (exchange of genetic information between different species, blocks of DNA). This horizontal gene transfer entirely dismantles the evolutionary lines; not only are genes, beyond genes, proteins and other cell components exchanged. Vertical gene transfer in the sense of the evolutionary lines that Darwin assumed to be omnipresent only developed after a certain level of complexity had been attained (Woese 2002).
} 
regard to the factors like (a) genome size, (b) genome G/C-proportion, (c) carbon utilization, and (d) oxygen tolerance.

Although the role of HGT in evolutionary processes was viewed with great scepticism only a few years ago (Kurland 2000, Kurland et al. 2003), today's results are so convincing that the current assumption is that the competences of those bacteria that associated to form the eukaryotic cell are important features of higher organisms. Bacteria also have the astounding capability to unite their bodies with other organisms and thus to symbiotically or parasitically use the surface of multicellular organisms as a habitat.

\subsection{Eukaryotic Revolution and Microbial Surface Expansion}

The development of cells with true nucleus - the eukaryotic revolution - in my opinion marks the beginning of a development of bacteria groups to conquer space and time: higher, complex lifeforms such as animals, fungi and plants are themselves inhabited from 60\%-90 \% by bacteria groups (Blech 2000). Through their symbiotic competence, the bacteria communities have conquered space (vertical extension, lateral expansion) and time (mobility). Based literally on the result of the first symbiogenesis, bacterial communities since then have accompanied all eukaryotic multicellular organisms as endo- or ectosymbionts around the entire planet. They have gained access to habitats and regions they never would have reached without these host organisms at the same time. The eukaryotic super-kingdom, thus, efficiently serves to expand the surface area available on our planet for settlement of the bacterial world.

\section{Symbiogenesis through "Merging", "Incorporation", "Fusion"?}

How can we envision these "merging" or "fusion" processes? The process is nothing less than a major change of protein individuals with certain inalienable attributes into protein individuals that differ essentially from their predecessors. This is a true revolutionary-evolutive process from simple to more complex organisms.

Lynn Margulis explained her postulated symbiogenetic processes in the classical language of mechanistic biology by terms like "merging", "fusion", "incorporation". Rather than involving "merging", "fusion", or "incorporation", we are dealing with regulative, constitutive and generative rule-governed signmediated interactions whose success depends upon whether the rule-governed sign processes (semioses) proceed or whether they fail, i.e., whether a new organism develops or not.

\subsection{Symbiogenesis in the Light of a Biology as an Understanding Social Science}

Over the past 20 years, the field of molecular biology has yielded a lot of scientific papers that describe in great detail the processes of recombinant DNA, RNA-editing, coding, copying, major and minor repairs, transcription, processing, translation, insertion, the importance of introns and exons, the complementary role of DNAs and RNAs, even the significance and indispensable features of non-coding DNA (CavalierSmith/Beaton 1999, Sternberg 2002, Baluska et al. 2004a, b; Shapiro/Sternberg 2004, Schmitt/Paro 2004).

In every case, enzyme proteins competent in text-processing are responsible for conducting these highly diverse procedures on proteincoding DNA. The remaining $97 \%$ of non-proteincoding DNA regions such as repetitive elements of introns have higher order regulatory functions in eukaryotic superkingdom (Mattick 2001, Mattick/Gagen 2001, Mattick 2003, Mattick 2005, Shapiro/Sternberg 2005). Both, protein coding DNA and non-proteincoding meta-DNA involve extreme precision, and mistakes in this textprocessing usually have grave consequences and are often lethal to the organism. 
Epigenetics, embryology and developmental genetics - to name but a few disciplines - have yielded a wealth of research results that underline the influence and dominance of the newly developed organism on reading of the genetic texts; the specific purpose is organismic development based on an incredible diversity of signalling pathways (Barbieri 2001, Beurton et al. 2000, Markos 2001, 2002).

All of these processes are far removed from "merging" in the sense of mechanistic changes in aggregate status: rather, they require highly complex interactions of a series of participants that are themselves genetically coded. The symbolic ("digital") code itself promotes the innate evolutive possibilities purposefully and by no means by chance, as it has been proved by a current report ${ }^{13}$ (Caporale 1998, 2003, 2004).

In the light of a biology as an understanding social science, these union processes are not fusions, mergings or linkages and are not analogous to physico-chemical changes in aggregate status, but are the results of molecular biological recombination processes, i.e. highly complex intra- and, from the epigenetic viewpoint, interorganismic rule-governed sign-mediated interactions.

The unbridgable gap between a mechanistic and the communicative concept is that rule-governed signmediated interactions are restricted to living individuals (-in-populations) and are not determined by natural laws solely, such as those that are fundamental preconditions for metabolism. The decisive difference between natural laws and semiotic rules is that every living being underlies natural laws in a strict sense. Semiotic rules may be followed or not, may be changed or not, may be generated or not. The fundamental difference between living nature and non-living nature is the difference between rule-governed signmediated interactions and natural laws.

In the meantime, more and more scientific articles have confirmed the SET theory in ever greater detail (Margulis et al. 2000, Dolan et al. 2002, Margulis/Sagan 2002, Searcy 2003, Berg/Kurland, 2002). This has led to a growing list of genes of eukaryotic microorganisms, animals, fungi and plants, but also of organs and tissues of eukaryotic organisms that have bacterial origins. It has decisively altered our understanding of the evolution of higher organisms: rather than involving chance mutations and the selection of the resulting phenotypes, the process involves an association via rule-governed signmediated interactions that underlie grammatical, semantic and pragmatic rules. Evolution is not a blind but rather a communicative (Witzany, 1993 b, 1997, 2000), not a chance but a cooperative, not determined by natural laws solely but rather a rule-governed, not mechanical but rather a biological phenomenon (Witzany 2003). Margulis has shown that the origin of the eukaryotic cell is a process of union, whereas the traditional forms of evolutionary theory are based on the opposite path, namely a branching and division. A central dogma of neo-Darwinism ${ }^{14}$ - the decisive function of mutations in the de novo evolution of organisms - thereby loses its validity-claim.

\footnotetext{
13 “ $(. .$.$) this means that DNA has the flexibility to carry multiple overlapping messages. Sure, genomes contain more than just genes:$ they also hold instructions about where in our body and when in our lives to make each protein. But what if our DNA also contained information that made mutation more likely in some parts of the genome and less likely in others? Such a genome would have the potential to influence its own evolution, protecting essential DNA sequences in some places while elsewhere unleashing genetic variations that could explore evolutionary possibilities" (Caporale 2004: preview text).

${ }^{14}$ Today we refer to post-Darwinism: "The principles of post-Darwinism, in brief:

(1) the main process for post-Darwinism is symbiosis and coherence (from which, in some conditions, competition may follow), whereas for neo-Darwinism it is competition (from which symbiosis sometimes follows);

(2) the first evolutionary event for neo-Darwinism is the mutation of DNA and the distribution of the new mutant (allele) in the population, whereas for post-Darwinism it is an ontogenetic change (a change in the usage of genetic memory), which is later followed by stochastic fixation in memory (mainly due to 'forgetting of the un-used');

(3) the entity making the choice in neo-Darwinism is the environment; in post-Darwinism it is the organism itself;

(4) for neo-Darwinism, DNA (together with environment) determines the entire structure and, in turn, also the behavior of the organism, whereas for post-Darwinism DNA is like a thesaurus or vocabulary from which the organism uses the entries it needs.

(5) for neo-Darwinism, the main role of sexual reproduction is to provide new genetic variants, whereas for post-Darwinism the importance of sexual reproduction comprises (a) the creation of species, and (b) forgetting of the unnecessary, i.e. making the genetic memory dynamic;

(6) generally, neo-Darwinism can be regarded as a restricted special case of post-Darwinism" (Kull 1999).
} 


\section{Conclusion: The communicative structure of Life}

Between 1987 and 1990 I developed a pragmatic philosophy of biology whose central thesis was a language-like structured and communicatively organized living nature. The pragmatic philosophy of biology is founded and justified (a) on an irreducible 3-leveled semiotics (syntactics, semantics and pragmatics) and on the (b) analyses of rule-governed sign-mediated interactions in the framework of a pragmatic theory of action which replaces the objectivistic-solipsistic subject of knowledge (objectivism, naturalism) of the linguistic turn by the intersubjective-communicative character of thought, experience and research.

This theory of communicating living nature postulates (a) that every living being is involved in intra-, inter- and metaorganismic communication processes whithout which any living being would not be able to live and (b) evolution in its decisive steps was regulated and constituted by a higher order genome function. The pragmatic philosophy of biology was first published in 1993 (Witzany 1993 b). At that time, its theses were - with the exception of Rupert Riedl, Thure von Uexküll and Wilhelm Vossenkuhl rejected by both philosophers and biologists. One philosopher muttered "He probably heard bacteria talking to one another." In the meantime, the course of development has proven this thesis correct on all counts.

"Using(...) advanced linguistic capabilities, bacteria can lead rich social lives for the group benefit. They can develop collective memory, use and generate common knowledge, develop group identity, recognize the identity of other colonies, learn from experience to improve themselves, and engage in group decisionmaking, an additional surprising social conduct that amounts to what should most appropriately be dubbed as social intelligence" (Ben Jacob 2004: 367).

In the framework of a language-like structured and communicatively organized living nature, evolution cannot be a process of chance mutations that are then selected; the evolutionary process was not subject to the strict mechanics of natural laws. Rather, it was a process that followed language-like and communicative rules, to which organisms have developed or can develop a relationship of adherence or non-adherence. The key steps of evolution - as the SET has demonstrated - were a union process of formerly independent gene bearers into integrated genomes. But this does not involve "merging", „amalgamation", "fusion", "incorporation" of genetic material, but it is only explainable through numerous enzyme proteins that are sufficiently competent to conduct highly complex text-processing, and RNAs which have similar abilities.

After innovation of eukaryotic protoctists, the constitution of a genetic higher order dataset in the phenotypic frame of multicellular eukaryotic superkingdom was regulated and constituted through the abilities of non-protein-coding regions of DNA, e.g., the repetitive elements of introns.

This hidden "meta-DNA" has been predicted as being necessary for explaining higher order functions such as combination, recombination, control and integration of large-scale structures of the chromosome (Witzany 1993b, Mantegna et al. 1994, Mattick 2001, Mattick/Gagen 2001, Mattick 2003, Mattick 2005, Shapiro/Sternberg 2005).

This changes our perception about the function and sense of evolution dramatically: No longer are small steps involving chance mutations responsible for differentiating eukaryotic organismic kingdoms, whose phenotypes were then subject to selection pressure. What numerous researchers always surmised, i.e., that chance mutations could not have brought about the enormous complexity of intracellular processes or this astounding diversity of organisms, has proven true. The arguments of neoDarwinism, that have vehemently defended this monistic (mutation/selection-)evolution over more than 
half a century, lose their validity. Mutations do occur, but they do not lead to a higher development of organisms, but rather to adaptational variants. They are fine-tunings and not originating factors for de novo evolution.

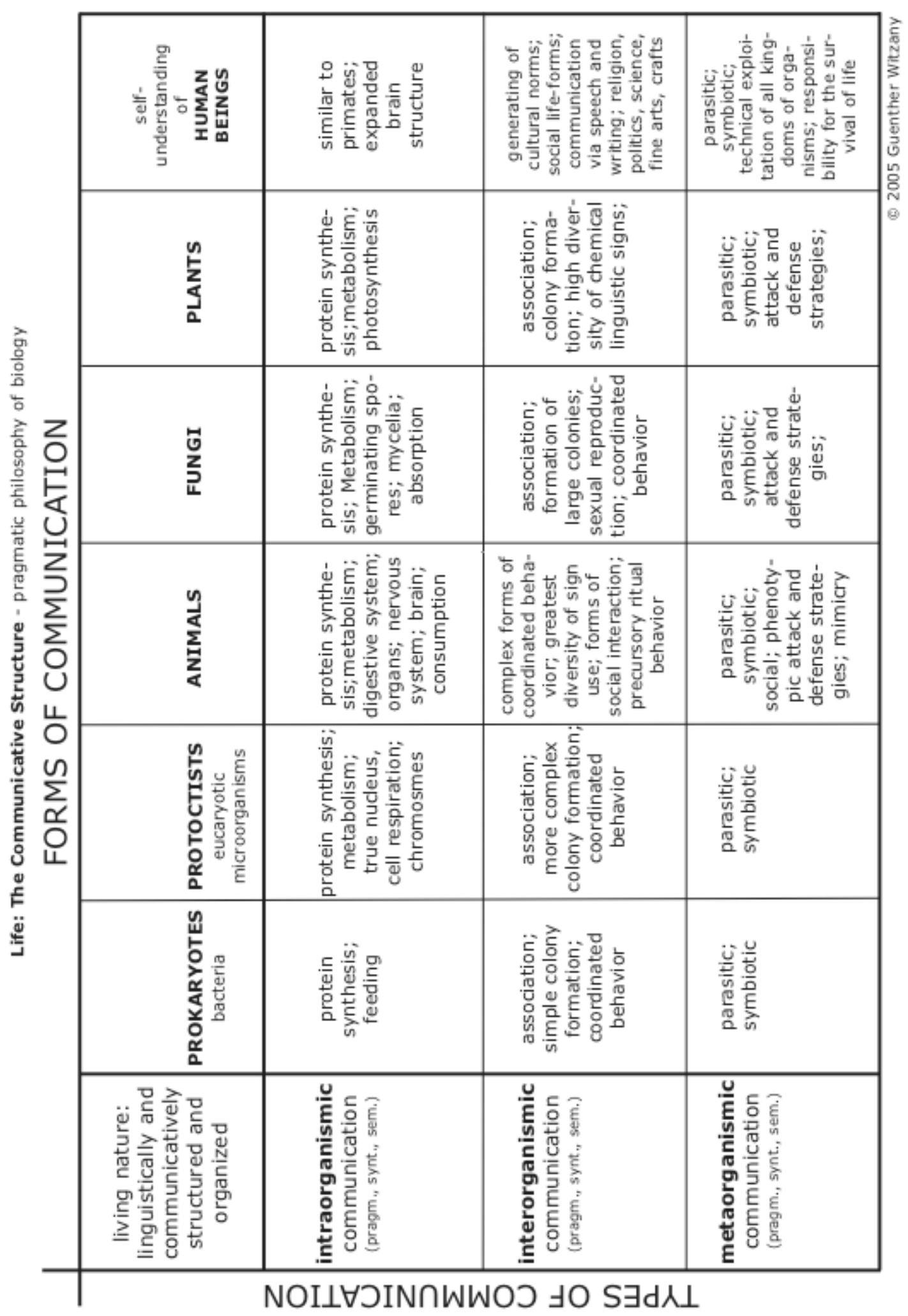


Through the union processes of genes of bacterial origin in the sense of SET, entire blocks of genes and, therefore, also phenotypically effective characters become components of such integration processes. Even the thesis - developed in the pragmatic philosophy of biology - of normal- and revolutionary-evolutive phases (Witzany 1993 b, 1997, 2000: 189-212), which attempts to explain the relatively saltatory development of new species, and that attempts to explain phenomena such as the Cambrian explosion or the absence of a large number of missing links, can be further developed: The innovation code I proposed, which is assumed to lie in the non-coding DNA, whose reading leads - as we know today - to active micro RNAs that have RNA/DNA-text-editing capabilities, gains a new interpretational basis in the framework of the SET. Accordingly, the "meta-DNA" coding only for active micro RNAs has (3-leveled) semiotic competences to incorporate entire blocks of DNA of foreign organisms (non-self-recognition!) in their own DNA, and to do this (1) at the correct location, and in (2) the correct relation to the existing genome ratio, i.e. also in the (3) correct relation to the DNA-skeletal noncoding-DNA-ratio.

New reports suggest that the capabilities of non-coding DNA with higher order regulatory functions descended from ancestral viral genome editing competences which had been integrated by endogenious retrovirus. There are strong reasons too, that also eukaryotic nucleus is of viral origin. DNA virus are held to be competent to create new genes in large numbers, complex and simple ones (Bell 2001, Ryan 2002, Villareal 2004).

The SET consciously sets aside the explanation of the origin of the first life-forms or protocells. The true nature of evolution from the beginning, namely as a language-like structured and communicatively organized process, provides good reasons for the thesis that even the de novo origin of life itself coincides with the genesis of rule-governed, sign-mediated interactions.

\section{References}

Apel, K.O. (1974) Zur Idee einer transzendentalen Sprachpragmatik. Die Dreistelligkeit der Zeichenrelation und die "abstractive fallacy" in den Grundlagen der klassischen Transzendentalphilosophie und der sprachanalytischen Wissenschaftslogik. In Simon, J. (Ed.) (1974) Aspekte und Probleme der Sprachphilosophie. Freiburg/München. Verlag Karl Alber, pp. 283-326.

Austin, J.L. (1962) How to Do Things with Words. , Oxford, UK. Oxford University Press.

Bais, H.P. et al. (2004) How plants communicate using the underground information superhighway. In: Trends in Plant Science, 9(1): 26-32.

Baluska F. et al. (2004 a) Eukaryotic Cells and their Cell Bodies: Cell Theory Revised. In: Annals of Botany, 94: 9-32.

Baluska, F. et al. (2004 b) Cell bodies in a cage. In: Nature, 428: 371.

Barbieri, M. (2001) The Organic Codes. The birth of semantic biology. PeQuod, Ancona.

Bassler, B.L. (1999) How bacteria talk to each other: Regulation of gene expression by quorum sensing. In: Current Opinion in Microbiology, 2: 582-587.

Batut, J. (2004) The Evolution of Chronic Infection Strategies in the -Proteobacteria. In: Nature Reviews, Microbiology, 2: 933-945. Ben Jacob, E. et al. (2004) Bacterial linguistic communication and social intelligence. In: Trends in Microbiology, 12(8): 366-372.

Bell, P. (2001) Viral eukaryogenesis: was the ancestor of the nucleus a complex DNA virus? In: Journal of Molecular Evolution, 53:251-256.

Berg, O. G./Kurland, C. G. (2002) Evolution of Microbial Genomes: Sequence Acquisition and Loss. In: Molecular Biology and Evolution, 19(12): 2265-2276.

Bernard, J. (2005) Invitation to the International Conference "Innovation and Reproduction in Cultures and Societies" in Vienna 2005, online paper.

Beurton, P. et al. (Eds.) (2000) The Concept of the Gene in Development and Evolution. Cambridge, UK. Cambridge University Press.

Blech, J. (2000) Leben auf dem Menschen. Die Geschichte unserer Besiedler. Rowohlt Taschenbuch Verlag, Hamburg.

Bloom, A.J./Holbrook, N.M. (2001) United Kingdoms. Meeting report. In: Plant Physiology, 126: 952-955.

Bloom, G.S./Goldstein, L.S.B. (1998) Cruising along microtubule highways: how membranes move through the secretory pathway. In: Journal of Cell Biology, 78: 297-304.

Brooke, N.M./Holland, P.W.H. (2003) The evolution of multicellularity and early animal genomes. In: Current Opinion in Genetics \& Development, 13: 599-603. 
Brownlee, C. (2002) Role of the extracellular matrix in cell-cell-signalling: paracrine paradigms. In: Current Opinion in Plant Biology, 5: 396-401.

Callaway, R.M. (2002) The detection of neighbors by plants. In: Trends in Ecology \& Evolution, 17: 104-105.

Caporale, L.H. (1998) Genomic Strategies for Evolutionary Adaptation: The rate, location and extent of genetic variation is not monotonous. In: InterJournal Genetics, 178.

Caporale, L.H. (2003) Natural selection and the Emergence of a Mutation Phenotype: An Update of the Evolutionary Synthesis Considering Mechanisms that Affect Genome Variation. In: Annual Review of Microbiology, 57: 467-485.

Caporale, L.H. (2004) Genomes don't play dice. In: New Scientist, March 2004, 42-51.

Cavalier-Smith, T./Beaton, M.J. (1999) The skeletal function of non-coding DNA: new evidence from ancient cell chimeras. In: Genetics, 106: 3-13.

Cavalier-Smith, T. (2002) Chloroplast evolution: secondary symbiogenesis and multiple losses. In: Current Biology, 12: 62-64.

Crespi, B.J. (2001) The evolution of social behavior in microorganisms. In: Trends in Ecology \& Evolution, 16: 178-183.

Crespi, B. and Springer, S. (2003) Social Slime Molds Meet Their Match. In: Science, 299: 56-57.

Dessaux Y. (2004) Biological Communications and Interactions in the Rhizosphere. Presented at "Rhizosphere 2004"-congress, 12.17. September, Munich/Germany.

Dierschke, H. (1994) Pflanzensoziologie: Grundlagen und Methoden. Ulmer Verlag.

Dolan, M. et al. (2002) Motility proteins and the origin of the nucleus. In: The Anatomical Record, 268: 290-301.

Douglas, A.E. (1998) Nutritional Interactions in Insect-Microbial Symbioses: Aphids and Their Symbiotic BacteriaBuchnera. In: Annual Review of Entomology, 43: 17-37.

Dunn, A.K./Handelsman, J. (2002) Toward an understanding of microbial communities through analysis of communication networks. In: Antonie van Leeuwenhoek, 81: 565-574.

Engelberth, J. et al. (2004) Airborne signals prime plants against insect herbivore attack. In: Proceedings of the National Academy of Sciences of the USA, 101(6): 1781-1785.

Estabrook, E.M./Yoder J.I. (1998) Plant-plant communications: rhizosphere signalling between parasitic angiosperms and their hosts. In: Plant Physiology, 116: 1-7.

Federle, M. J./Bassler, B. L. (2003) Interspecies communication in bacteria. In: The Journal of Clinical Investigation, 112(9): 12911299.

Fleming, A. (ed.) (2005) Intercellular Communication in Plants. In: Annual Plant Reviews, 16.

Fox, J.E. (2004) Chemical Communication Threatened by Endocrine-Disrupting Chemicals. In: Environmental Health Perspectives, 112(6): 648-652.

Frisch, K.v. (1971) Bees: Their Vision, Chemical Senses and Language. Ithaca. Cornell University Press.

Fuqua, C. et al. (1996) Census and Consensus in bacterial ecosystems: The LuxR-Luxl family of quorum sensing transcriptional regulators. In: Annuals Review of Microbiology, 50: 727-751.

Gerrish, P. (2001) The rhythm of microbial adaptation. In: Nature, 413: 299-302.

Habermas, J. (1984) The Theory of Communicative Action 1. Boston. Beacon Press.

Habermas, J. (1987) The Theory of Communicative Action 2. Boston. Beacon Press.

Habermas, J. (1989) Knowledge \& Human Interests. Cambridge, UK. Polity Press.

Habermas, J. (1994) Actions, speech acts, linguistically mediated interactions and the lifeworld. In: Floistad, G (Ed.) (1994)

Philosophical problems today, 1: 45-74.

Heidegger, M. $\left({ }^{15} 1979\right)$ Sein und Zeit. Tübingen. Max Niemeyer.

Hirsch, A.M. et al. (2003) Molecular signals and receptors: controlling rhizosphere interacting between plants and other organisms. In: Ecology, 84: 858-868.

Hoffmeyer, J. (1996) Signs of Meaning in the Universe. Bloomington/Indiana. USA. Indiana University Press-

Hooper, L.V. et al. (1998) Host-microbial symbiosis in the mammalian intestine: exploring an internal ecosystem. In: Bioessays, 20(4): 336-343.

Imaizumi-Anraku, H. et al. (2005) Plastid proteins crucial for symbiotic fungal and bacterial entry into plant roots. In: Nature, 433 : 527-531.

Jain, R. et al. (1999) Horizontal gene transfer among genomes: the complexity hypothesis. In: Proceedings of the National Academy of Sciences of the USA, 96: 3801-3806.

Jain, R. et al. (2003) Horizontal Gene Transfer Accelerates Genome Innovation and Evolution. In: Molecular Biology and Evolution, 20(10): 1598-1602.

Ji, S. (1999) The Linguistics of DNA: Words, Sentences, Grammar, Phonetics, and Semantics. In: Annals New York Academy of Sciences, 870: 411-417.

Kandel, E.R. (2001) The molecular biology of memory storage. A dialogue between genes and synapses. In: Science, 294: 10301038.

Kahmann, R./Basse, C. (2001) Fungal gene expression during pathogenesis-related development and host plant colonization. In: Current Opinion in Microbiology, 4(4): 374-380.

Kaiser, D. and Losick, R. (1993) How and why Bacteria Talk to Each Other. In: Cell, 73(5): 873-85.

Keyes, WJ. et al. (2000) Signaling organogenesis in parasitic angiosperms: xenognosin generation, perception, and response. In: Journal of Plant Growth Regulation, 19: 217-231. 
Knight, R. D. et al. (2001) Rewiring the Keyboard: Evolvability of the Genetic Code. In: Nature Reviews Genetics, 2: 49-58.

Kreft, J.U. (2004) Biofilms promote altruism. In: Microbiology, 150: 2751-2760.

Kolenbrander, P.E. et al. (2002) Communication among Oral Bacteria. In: Microbiology and Molecular Biology Reviews, 66(3): 486-

505.

Kowallik, K.V. (1999) Endosymbiose - ein Motor der Evolution. In: biologen heute, 1.

Kull, K. (1999) Outlines for a Post-Darwinian Biology. In: Folia Baeriana, 7: 129-142.

Kull, K. (2005) A brief history of Biosemiotics. In: Journal of Biosemiotics, 1: 1-34.

Kurland, C.G. (2000) Something for everyone- Horizontal gene transfer in evolution. In: EMBO Reports, 1(2): 92-95.

Kurland, C.G. et al. (2003) Horizontal gene transfer: A critical view. In: Proceedings of the National Academy of Sciences of the USA, 100(17): 9658-9662.

Lemos, B. et al. (2004) Regulatory evolution across the protein interaction network. In: Nature Genetics, 36: 1059-1060.

Losick, R./Kaiser, D. (1997) Why and how Bacteria Communicate. In: Scientific American, 2: 52-58.

Mantegna, R.N. et al. (1994) Linguistic Features of Noncoding DNA Sequences. In: Physical Review Letters, 73(23): 3169-3172.

Margulis, L. (1996) Archaeal-eubacterial mergers in the origin of Eukarya: Phylogenetic classification of life. In: Proceedings of the National Academy of Sciences of the USA, 93: 1071-1076.

Margulis, L. (1999) Die andere Evolution. Heidelberg. Spektrum Akademischer Verlag.

Margulis, L., et al. (2000) The chimeric eukaryote: origin of the nucleus from the karyomastigont in an amitochondriate protist. In:

Proceedings of the National Academy of Sciences of the USA, 97: 6954-6959.

Margulis, L. and Sagan, D. (2002) Acquiring Genomes. A Theory of the Origin of Species. Basic Books, New York.

Margulis, L. (2004) Serial endosymbiotic theory (SET) and composite individuality. Transition from bacterial to eukaryotic genomes.

In: Microbiology Today, 31: 173-174.

Markos, A. (2001) Advanced molecular biology. Course outline 2001/02, online paper.

Markos, A. (2002) Readers of the Book of Life. Oxford, New York. Oxford University Press.

Mattick, J.S./Gagen, M.J. (2001) The Evolution of Controlled Multitasked Gene Networks: The Role of Introns and Other Noncoding RNAs in the Development of Complex Organisms. In: Molecular Biology and Evolution, 18(9): 1611-1630.

Mattick, J.S. (2001) Non-coding RNAs: the architects of eukaryotic complexity. In: EMBO reports, 2(11): 986-991.

Mattick, J.S. (2003) Challenging the dogma: the hidden layer of noncoding RNAs in complex organisms. In: BioEssays, 25(10): 930.

Mattick, J.S. (2005) Das verkannte Genom-Programm. In: Spektrum der Wissenschaft 3: 62-69.

McCarthy, T. (1984) Translator's Introduction. In: Habermas, J. (1984)The Theory of Communicative Action 1. Boston. Beacon

Press. p. ix.

McFall-Ngai, M. J. (2002) Unseen Forces: The Influence of Bacteria on Animal Development. In: Developmental Biology, 242: 1-14.

Montana State University (1999) Cell-Cell Communication Collection. Center of Biofilm Engineering, online paper,

http://www.erc.montana.edu/Res-Lib99-SW/Image_Library/Cell-Cell_Communication/default.htm.

Morris, C.W. (1945) The Significance of the Unity of Science Movement. In: Philosophy and Phenomenological Research, 6: 512.

Pattee, H. H. (2005) The Physics and Metaphysics of Biosemiotics. In: Journal of Biosemiotics, 1: 281-301.

Perbal, B. (2003) Communication is the key. In: Cell Communication and Signaling, 1: 3.

Ryan, F. (2002) Darwin's blind spot: evolution beyond natural selection. Boston. Houghton Mifflin Company.

Romano, J.D. and Kolter, R. (2005) Pseudomonas-Saccharomyces Interactions: Influence of Fungal Metabolism on Bacterial

Physiology and Survival. In: Journal of Bacteriology, 187(3): 940-948.

Schauder, S./Bassler, B. L. (2001) The languages of bacteria. In: Genes \& Development, 15: 1468-1480.

Schauder, S. et al. (2001) The LuxS-family of bacterial autoinducers: Biosynthesis of a novel quorum sensing signal molecule. In: Molecular Microbiology, 41(2): 463-76.

Searle, J.R. (1976) Speech Acts. An Essay in the Philosophy of Language. Cambridge. Cambridge University Press.

Searls, D.B. (1992) The Linguistics of DNA. In: American Scientist, 80: 579-591.

Searls, D.B. (2002) The language of genes. In: Nature, 420: 211-217.

Searcy, D.G. (2003) Metabolic integration during the evolutionary origin of mitochondria. In: Cell Research, 13: 229-238.

Seeley, T.D. (1995) The Wisdom of the Hive. Cambridge. Harvard University Press.

Schmitt, S./Paro, R. (2004) A reason for reading nonsense. In: Nature, 429: 510-511.

Shapiro, J.A./Sternberg, R.v. (2005) Why repetitive DNA is essential to genome function. In: Biological Review, 80: 1-24.

Sharma, A. et al. (2003) Microbial communication in the rhizosphere: Operation of quorum sensing. In: Current Science, 85(8): 11641172.

Skusa, A. (2003) Reconstruction of intercellular communication networks. Presented at the European Conference on Computational Biology (ECCB 2003), Paris, September 27-30.

Stechmann, A./Cavalier-Smith, T. (2003) The root of the eukaryote tree pinpointed. In: Current Biology, 13(17): 665-666.

Sternberg, R.v. (2002) On the Roles of Repetitive DNA Elements in the Context of a Unified Genomic-Epigenetic System. In: Annals of the New York Academy of Sciences, 981: 154-188.

Tamames, J. (2001) Evolution of gene order conservation in prokaryotes. In: Genome Biology, 2(6): 1-11.

Teplitski, M. et al. (2000) Plants secrete substances that mimic bacterial $\mathrm{N}$-acyl homoserine lactone signal activities and affect population density-dependent behaviours in associated bacteria. In: Molecular Plant-Microbe Interaction, 13: 637-648. 
Timmis, J.N. et al. (2004) Endosymbiotic gene transfer: organelle genomes forge eukaryotic chromosomes. In: Nature Reviews Genetics, 5: 123-135.

Trewavas, A. (2001) How plants learn. In: Proceedings of the National Academy of Sciences of the USA, 96: 4216-4218.

Trewavas A. (2003) Aspects of Plant Intelligence. In: Annals of Botany, 92: 1-20.

Uexkuell, Th.v. (1989) Naturwissenschaft als Zeichenlehre. In: Merkur, 3: 225-234.

Velicer, G. J. (2003) Social strife in the microbial world. In: Trends in Microbiology, 11(7): 330-337.

Villarreal, LP. (2004) Can Viruses Make Us Humans? In: Proceedings of the American Philosophical Society, 148(3):296-323.

Vossenkuhl, W. (1998) "Verstehen" verstehen. In: Kanitscheider, B./Wetz, F.J. (Eds.) (1998) Hermeneutik und Naturalismus.

Tübingen. Mohr Siebeck,.

Wagner, E. et al. (1999) From Symbiosis to Eukaryotism. In: ENDOCYTOBIOLOGY VII. Proceedings of the International Congress on Endocytobiology, Symbiosis and Biomedicine, University of Freiburg, University of Geneva.

Walker, T.S. (2003) Root exudation and Rhizosphere Biology. In: Plant Physiology, 132: 44-51.

Walters, R.J. (1997) The language of the cell. In: Cellscience, online paper.

Waugh, A. (2002) RNAML: A standard syntax for exchanging RNA information. In: RNA, 8: 707-717.

Witzany, G. (1993 a) Zeichenprozesse als Bedingungen der Möglichkeit von Leben und Evolution. In: Zeitschrift für Semiotik, 15(1/2): 107-125.

Witzany, G. (1993 b) Natur der Sprache - Sprache der Natur. Sprachpragmatische Philosophie der Biologie. , Würzburg. Königshausen \& Neumann.

Witzany, G. (1995) From the "logic of the molecular syntax" to molecular pragmatism. In: Evolution and Cognition, 1(2): 148-168.

Witzany, G. (1997) Semiosis and Evolution. Semiotics Around the World: Synthesis in Diversity. In: Rauch, I. (Ed.) (1997) Berlin. Mouton de Gruyter. pp. 977-980.

Witzany, G. (1998) Explaining and Understanding LIFE. In: Semiotica, 120(3/4): 421-438.

Witzany, G. (2000) Life: The Communicative Structure. A New Philosophy of Biology. Norderstedt. Libri Books on Demand.

Witzany, G. (2002 a) Reduction of biological phenomena? Deficits of systems theory and the alternatives. In: Schmitz, W. (ed) (2002) Sign Processes in Complex Systems. Berlin/New York. Mouton de Gruyter. pp 303-307.

Witzany, G. (2002 b) Sprache und Kommunikation als zentrale Struktur- und Organisationsprinzipien belebter Natur. In: Albers, L.I Leiß, O. (Eds.) (2002) Körper-Sprache-Weltbild. Integration biologischer und kultureller Interpretationen in der Medizin. Stuttgart/New York. Schattauer. pp. 87-96.

Witzany, G. (2003) Metaphysics in Physics and Biology. Presented at the meeting of the International Society for the History, Philosophy and Social Studies of Biology, Vienna 2003.

Witzany, G. (2005) Natural history of life: History of communication logics and dynamics. In: S.E.E.D. Journal, 5(1): 27-55. Woese, C.R. (2002) On the evolution of cells. In: Proceedings of the National Academy of Sciences of the USA, 99: 8742-8747. Wolf, Y.I. (1999) Evolution of Aminoacyl-tRNA Synthetases-Analysis of Unique Domain Architectures and Phylogenetic Trees Reveals a Complex History of Horizontal Gene Transfer Events. In: Genome Research, 9: 689-710.

Wolf, Y.I. (2000) Genome Alignment, Evolution of Prokaryotic Genome Organization, and Prediction of Gene Function Using Genomic Context. In: Genome Research, 11: 356-372.

Xie G. et al. (2004) Inter-genomic displacement via lateral gene transfer of bacterial trp operons in an overall context of vertical genealogy. In: BioMedCentral Biology, 2: 15.

Yoder, J.I. (1999) Parasitic plant responses to host plant signals: a model for subterranean plant-plant interactions. In: Current Opinion in Plant Biology, 2: 65-70.

Zook, D. (1998) A New Symbiosis Language. In: ISS Symbiosis News, 1(3): 1-3. 